\title{
Correlative geochemical study of crude oils from southeastern and southern parts of the Pannonian Basin
}

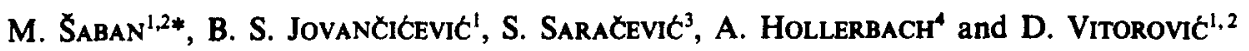 \\ IInstitute of Chemistry, Faculty of Science, University of Belgrade, P.O. Box 550, Yu-11001, \\ Belgrade, Yugoslavia \\ ${ }^{2}$ Institute of Chemistry, Technology and Metallurgy, Belgrade \\ ${ }^{3}$ Nafta-Gas, Novi Sad, Yugoslavia \\ "Institute for Petroleum Research, Clausthal-Zellerfeld, F.R.G.
}

\begin{abstract}
Several crude oils from the southeastern Yugoslav part of the Pannonian Basin are correlated for the first time on the basis of many bulk and specific parameters. The investigations involved 15 oils from oil-gas fields $A$ and $B$ and oil field $C$ from the Banat depression and oil field D from South Backa depression, and four oils from recently discovered oil shows $\mathrm{E}$ (the Kostolac depression). On the basis of structural group analysis and other bulk parameters such as API gravity, contents of asphaltenes and sulfur, as well as content of $n$-alkanes and pristane to phytane ratio, the examined oils are classified into four groups. However, the distributions and relative abundances of $n$-alkanes, isoprenoids $\left(C_{19}, C_{20}\right)$, steranes, tricyclic terpanes and pentacyclic triterpanes, obtained by capillary GC and computerized GC-MS analysis, suggest classification of the examined oils into only two genetic types: $A-D$ and $E_{1}-E_{4}$. The oils are of relatively high maturity. They are not biodegraded, except for both oils from field $D$ and the oil $A_{9}$.
\end{abstract}

Key words: oil-oil correlations, Pannonian Basin crude oils, bulk correlation parameters, specific correlation parameters, classification of Pannonian Basin crude oils, molecular source parameters, maturation parameters

\section{INTRODUCTION}

During the last 30 years several oil and oil-gas fields have been discovered in Yugoslavia, i.e. the southeastern part of the Pannonian Basin. This part of the Basin had not yet been completely explored. Since oil-oil correlations can be one of the valuable tools for assisting exploration geologists, the present study was undertaken to assess the relationship between several major oil accumulations on the basis of a few bulk and molecular parameters.

The Pannonian Basin (Fig. 1) represents one part of a broad basin which was formed by rising of the Alps, Carpathian and Dinaric Alps and by lowering of the terrain between their ranges. During evolution, the depressed parts of this area were filled by Tertiary sediments whose depth reached several thousand meters in places (Aksin, 1967).

The very complex structure of the Pannonian Basin resulted from complicated geologic and tectonic relationships in this district. The rôle of the differential movements, mainly lowering and, to a smaller extent, lifting the basin together with the Tertiary sediments, was very important in the formation of the present tectonic configuration. A large number of marginal depressions was thus formed. In the southeastern part of the Pannonian Basin several separate tectonic units formed: the Banat (B), South Backa (SB), Srem (S), Danubian (D) and Kostolac depressions (K). Most of the oil and gas fields in this part of the

*Author to whom correspondence should be addressed.
Basin were found in the largest, the Banat depression. Commercial hydrocarbon reservoirs were also found in the South Bačka and Danubian depressions. In contrast, so far, exploration in the area of the Srem depression is not economic. Finally, recent exploratory drillings in the Kostolac depression are positive, so that this area also becomes very significant.

This paper involves examination of oils from two oil-gas fields (A and B) and one oil field (C) of the Banat depression and one oil field (D) of the South Backa depression. Furthermore, samples from four newly discovered oil shows in the Kostolac depression $\left(E_{1}-E_{4}\right)$ were also investigated. The oil-gas fields $A$ and $B$ are located in the region of North Banat, the oil fields $C$ and $D$ in the area of North Backa, and the oil shows $E_{1}-E_{4}$ in northeastern Serbia, i.e. in the southern part of the Pannonian Basin (Fig. 1).

On the basis of earlier geological investigations, carried out by the company Nafta-Gas from Novi Sad, as well as geochemical analyses of trace elements and physical and chemical properties, the crude oils from oil fields A, B, C and D are classified into three genetic types: type I oil-gas field A, type II oil-gas field $B$ and oil field $C$, and type III oil field D. For the first two types of oils the presumed source rocks are of Neogene and for type III of Mesozoic age (Sarković, 1972). A recent preliminary correlation study, based on trace elements, confirmed the different genetic types of oils from oil fields A and D (Saban et al., 1984).

Since oil-oil correlations based on qualitative and quantitative biomarker analyses have been shown to 


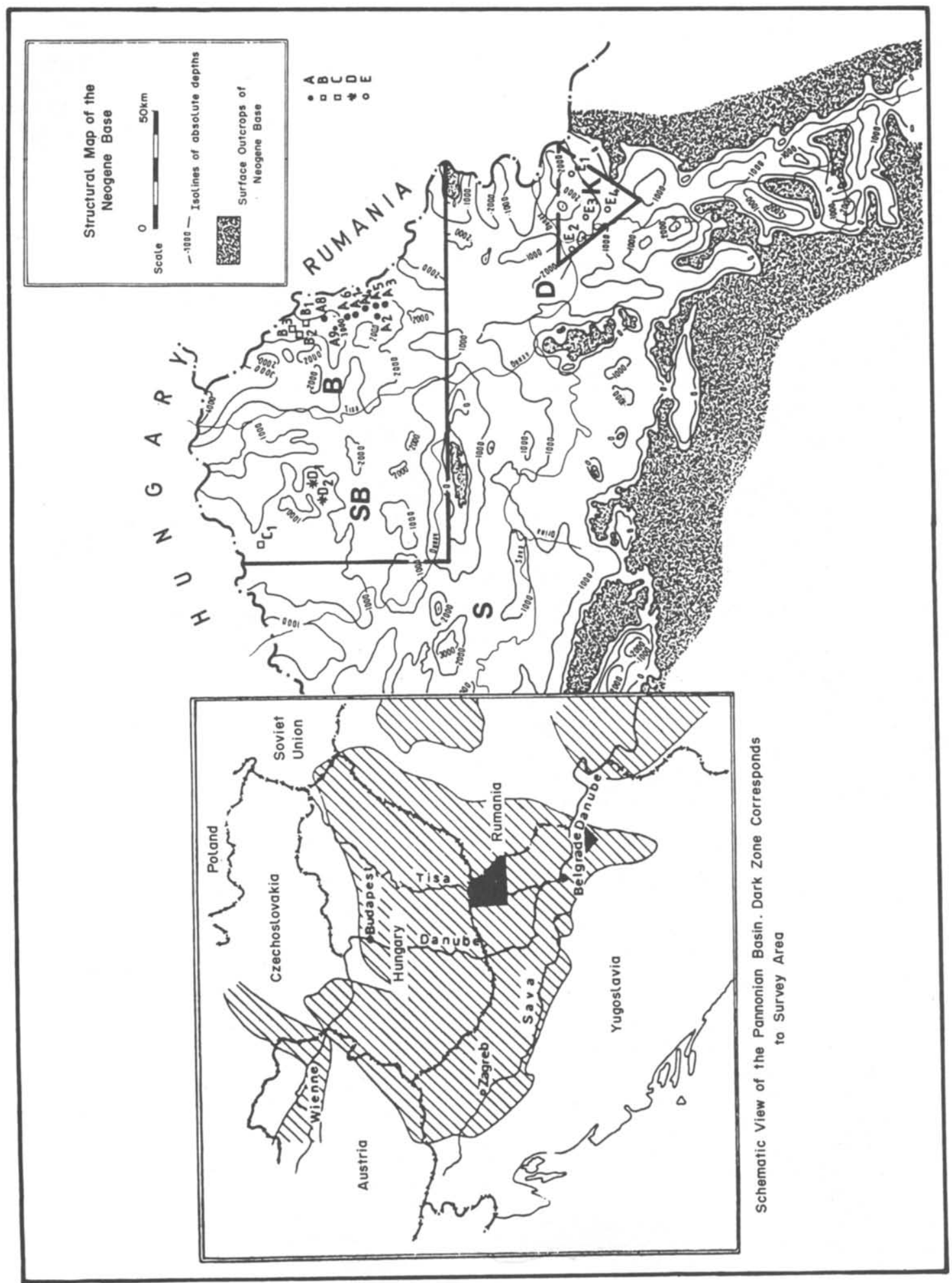

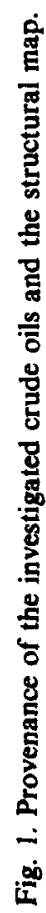


be very efficient (e.g. Welte et al., 1975; Seifert and Moldowan, 1978, 1979, 1981; Seifert et al., 1983; McKirdy et al., 1983; Palacas et al., 1986; Riva et al., 1986), this study also attempted correlation and classification of the oils on the basis of specific parameters such as the distribution of $n$-alkanes, isoprenoid and polycyclic alkanes. Parallel with the specific parameters, several bulk parameters were also determined: API gravity, sulfur content and structural group composition.

\section{SAMPLING AND ANALYTICAL TECHNIQUES}

Both the oil-gas fields $A$ and $B$ have a larger number of oil and/or gas reservoirs located in different lithologic and chronostratigraphic horizons, while the oil fields $C$ and $D$ involve only one accumulation each. From oil-gas field $A$ nine samples were analyzed $\left(A_{1}-A_{9}\right)$ from different reservoirs representing separate hydrodynamic systems. Three samples were analyzed from the oil-gas field $B\left(B_{1}-B_{3}\right)$, one sample from oil field $C\left(C_{1}\right)$, and two samples from oil field $\mathrm{D}\left(\mathrm{D}_{1}\right.$ and $\left.\mathrm{D}_{2}\right)$. One sample was analyzed from each of the four oil shows of the Kostolac depression $\left(E_{1}-E_{4}\right)$. The sampling locations are indicated in Fig. 1.
Geological data on the reservoir rocks of the analyzed samples are shown in Fig. 2.

The oils were sampled in front of the spout on the collector into glass bottles prepared according to the ASTM standard procedure.

The water and the dispersed solid material were separated by centrifugation. From the oils thus purified the asphaltenes were precipitated by treatment with $n$-heptane for $16 \mathrm{~h}$ at room temperature and then $15 \mathrm{~min}$ at the solvent boiling temperature. The solvent and the low boiling components were eliminated from the filtrate at $50^{\circ} \mathrm{C}$ in a rotating vacuum evaporator. The structural group composition of the obtained $\mathrm{C}_{15}+$ fraction was determined by column chromatography (Seifert and Moldowan, 1978).

Gas chromatographic (GC) analyses of saturated hydrocarbons and urea adducts were carried out with a Varian 3300 gas chromatograph using a $25 \mathrm{~m}$ $\times 0.25 \mathrm{~mm}$ i.d. fused silica DB-1 capillary column directly connected to an FID detector. Gas chromatographic-mass spectrometric (GC-MS) analyses of urea nonadducts were performed with a system consisting of a Perkin-Elmer Sigma 1 GC fitted with a $30 \mathrm{~m} \times 0.25 \mathrm{~mm}$ i.d. fused silica DB-1 capillary column coupled to a Hewlett-Packard 5970 mass selective detector and a Hewlett-Packard 9816 com-

\begin{tabular}{|c|c|c|c|c|}
\hline \multicolumn{2}{|c|}{$A G E$} & $\begin{array}{l}\text { LITHOLOGICAL } \\
\text { SYMBOLS }\end{array}$ & L I THOLOGY & $\begin{array}{c}\text { OIL SAMPLES } \\
\text { DEPTH (m) } \\
\text { TEMPERATURE OF RESERVOIR ROCKS }\left(\mathrm{c}^{\circ}\right)\end{array}$ \\
\hline \multicolumn{2}{|c|}{ QUATER N A K Y } & & $\begin{array}{l}\text { CLAY WIGRAVEL } \\
\text { CLAY, SAND }\end{array}$ & \\
\hline \multirow{7}{*}{$\begin{array}{l}\text { w } \\
z \\
0 \\
0 \\
0 \\
0 \\
z\end{array}$} & $\begin{array}{l}\text { PALUDINE } \\
\text { LAYERS }\end{array}$ & & $\begin{array}{l}\text { SAND, CLAYS, } \\
\text { CLAYEY SAND AND SANDY CLAY }\end{array}$ & $\begin{array}{ccccc}A_{9} & A_{4} & A_{2} & A_{7} & A_{5} \\
1158-1153 & 1200-1196 & 1221-12171209-1207 & 1390-1389 \\
66.6 & 60.1 & 105.0 & \text { N.D. } & 84.0\end{array}$ \\
\hline & $\begin{array}{l}\text { UPPER } \\
\text { PONTAIN }\end{array}$ & & $\begin{array}{l}\text { SANDY CLAY } \\
\text { CLAYEY SAND AND SAND }\end{array}$ & \\
\hline & $\begin{array}{l}\text { LOWER } \\
\text { PONTIAN }\end{array}$ & & $\begin{array}{l}\text { MARLS, } \\
\text { SANDY MARLSTONES, SAND }\end{array}$ & \begin{tabular}{ccccc|}
$\mathrm{D}_{1}$ & $\mathrm{D}_{2}$ & $\mathrm{~A}_{3}$ & $\mathrm{~B}_{2}$ & $\mathrm{~B}_{3}$ \\
$753-747$ & $759-753$ & $1730-1781$ & $2098-2097$ & $2097-2091$ \\
65.3 & 60.9 & N.D. & 108.7 & N.D.
\end{tabular} \\
\hline & PANNONIAN & & $\begin{array}{l}\text { MARLS, SANDSTONES, } \\
\text { MARLSTONES }\end{array}$ & \\
\hline & SARMATIAN & & $\begin{array}{l}\text { LIMESTONES, SANDSTONES, } \\
\text { MARLSTONES AND CLAYS }\end{array}$ & \\
\hline & TORTONIAN & & $\begin{array}{l}\text { ORGANOGENIC LIMESTONES, } \\
\text { SANDSTONES, MARLY SANDSTONES } \\
\text { AND CLAYS, } \\
\text { VOLCANOGENIC SEDIMENTS } \\
\text { AND PYROCLASTS }\end{array}$ & $\begin{array}{cc}{ }_{B} & B_{1} \\
1942-1897 & 2017-2012 \\
107.5 & \text { N.D. }\end{array}$ \\
\hline & $\begin{array}{l}\text { OLIGOCENE- } \\
\text {-MIOCENE }\end{array}$ & & $\begin{array}{l}\text { BRECCIAS, SANDSTONES, } \\
\text { CLAYS AND CLAYSTONES' }\end{array}$ & $\begin{array}{cccc}E_{1} 1774-1762 & E_{2} 374.2304 \\
97.7 & E_{3} 2023-2018 & E_{4} 19321928 \\
\end{array}$ \\
\hline \multicolumn{2}{|c|}{ PALEOGENE } & & $\begin{array}{l}\text { SANDSTONES AND } \\
\text { CLAYSTONES-FLYSCH }\end{array}$ & \\
\hline \multirow{3}{*}{ 怘 } & CRETACEOUS & & $\begin{array}{l}\text { CLAYSTONES AND } \\
\text { SCAYSTY SANDSTONES }\end{array}$ & \\
\hline & JURASSIC & & $\begin{array}{l}\text { CLAYSTONES SCHISTY } \\
\text { SAHDSTONES-FLYSCH }\end{array}$ & \\
\hline & TRIASSIC & & SCEISTY SANDSTONES & $\begin{array}{ll}C_{1} & \text { N.D. } \\
& 73.0 \\
\end{array}$ \\
\hline \multicolumn{2}{|c|}{$\begin{array}{ll} & \text { PALEOZOIC } \\
\text { AND PRECAMBRIAN } \\
\end{array}$} & & $\begin{array}{l}\text { CRYSTALLINE SCHISTS } \\
\text { SERPENTINE PHYLLITE }\end{array}$ & $A_{1} \begin{array}{c}1729-1722 \\
105.9\end{array}$ \\
\hline
\end{tabular}

Fig. 2. Generalized section of the SE part of the Pannonian Basin showing the stratigraphic relationship of the oils studied. 


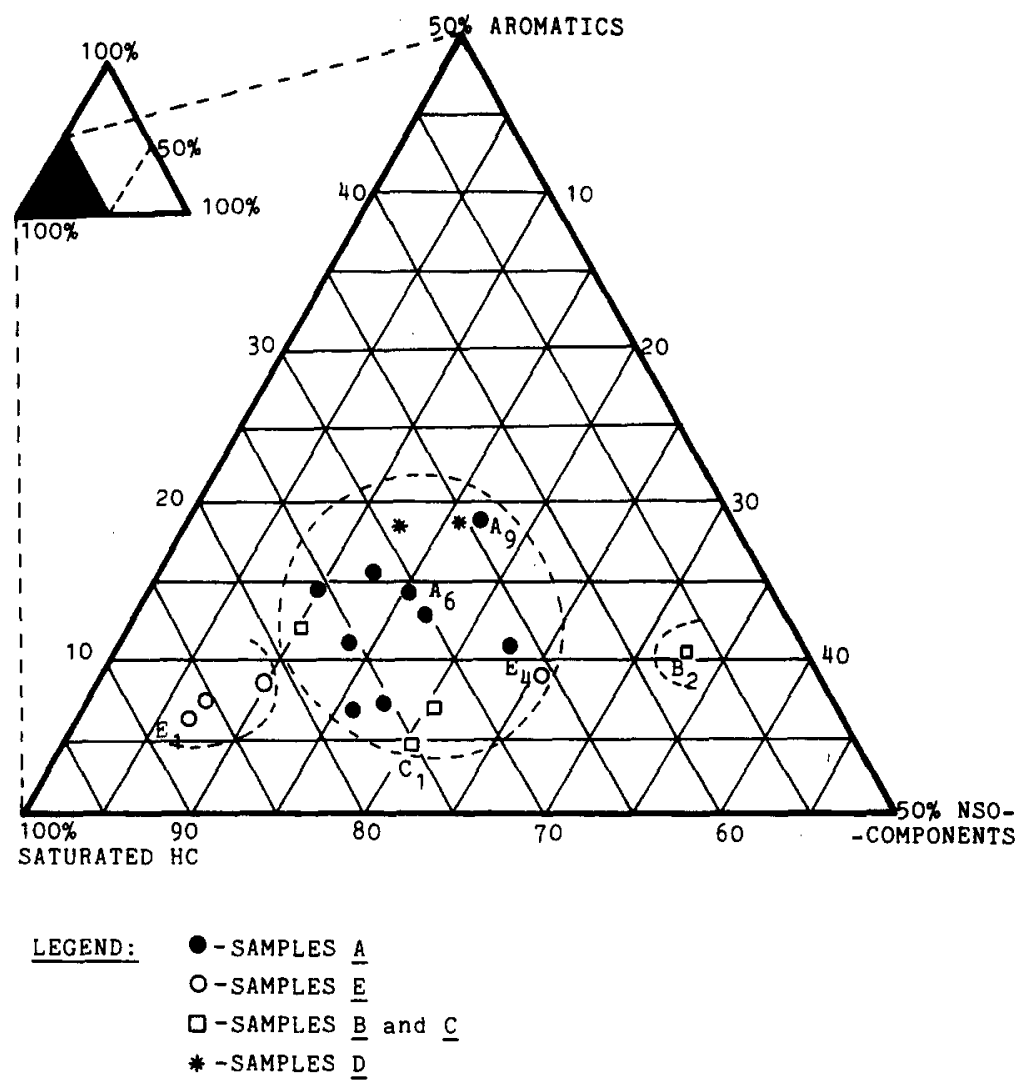

Fig. 3. The composition of analyzed oils.

puter. Each sample was analyzed in the SIM (selected ion monitoring) mode. The individual components were identified by comparison of the retention times with literature data (Philp, 1985).

The API gravity was determined according to the IP standard No. 160/68, 1977. The sulfur content was determined by microanalysis.

\section{RESULTS AND DISCUSSION}

The bulk and specific parameters determined for each of the 19 analyzed oil samples suggest possible correlation with regard to source material, maturity, biodegradation and migration.

\section{Correlations based on bulk parameters}

The composition according to different classes of compounds of the $\mathrm{C}_{15}+$ fraction of the oils (Fig. 3) shows the content of saturated hydrocarbons to be $65-77 \%$ in most of the samples, of aromatics $7-17 \%$ and of NSO-compounds 13-27\%. Somewhat higher content of saturated hydrocarbons, $82-87 \%$, and lower content of NSO-compounds, 7-10\%, were found in samples $E_{1}-E_{3}$. Another exception was the sample $B_{2}$ with only $57 \%$ of saturated hydrocarbons and $33 \%$ of NSO-compounds.

However, other bulk parameters such as API gravity, percentage sulfur and asphaltenes, as well as specific parameters obtained from saturated hydro- carbons such as content of $n$-alkanes relative to total saturated hydrocarbons and pristane to phytane ratio $(\mathrm{Pr} / \mathrm{Ph})$, shown in Fig. 4, indicated that a more precise differentiation of the examined oils was possible.

The oils from the oil-gas field $A$ are rather uniform, their parameters being in a narrow range. Sample $A_{9}$ is the only one to differ from the others. It has a somewhat smaller API gravity (23.8 vs $35.1-$ 42.3 ), higher contents of sulfur (0.52 vs $0.19-0.37 \%)$ and asphaltenes $(0.69$ vs $0.11-0.52 \%)$ and a lower conterit of $n$-alkanes ( 15.39 vs $40.67-57.94 \%$ ). Compared to other oils from this field, the $A$, is a heavy oil. This may be explained by possible biodegradation of this crude oil. However, a somewhat lower $\mathrm{Pr} / \mathrm{Ph}$ ratio $(0.46$ vs $0.70-1.08)$ may also indicate a distinct genetic source type for this oil.

Sample $A_{6}$, just as $A_{9}$, also has somewhat lower API gravity (23.5) and a higher content of sulfur $(0.87 \%)$ but other parameters are in the range observed for oils $A_{1}-A_{5}, A_{7}$ and $A_{8}$. Hence, according to these bulk parameters and the $\mathrm{Pr} / \mathrm{Ph}$ ratio, sample $A_{6}$ could not be classified as a distinct type.

The oil $B_{2}$ from oil-gas field $B$ differs from oils $B_{1}$ and $B_{3}$ which, on the other hand, do not differ from oils $A_{1}-A_{8}$. Sample $B_{2}$ has a somewhat lower API gravity (39.4 vs $39.8-44.5$ ), but considerably higher sulfur content ( 0.77 vs $0.21-0.33 \%)$, higher percentage of asphaltenes ( 2.26 vs $0.07-0.36 \%)$, lower content of $n$-alkanes (42.30 vs 54.67-50.61\%) and a lower $\mathrm{Pr} / \mathrm{Ph}$ 


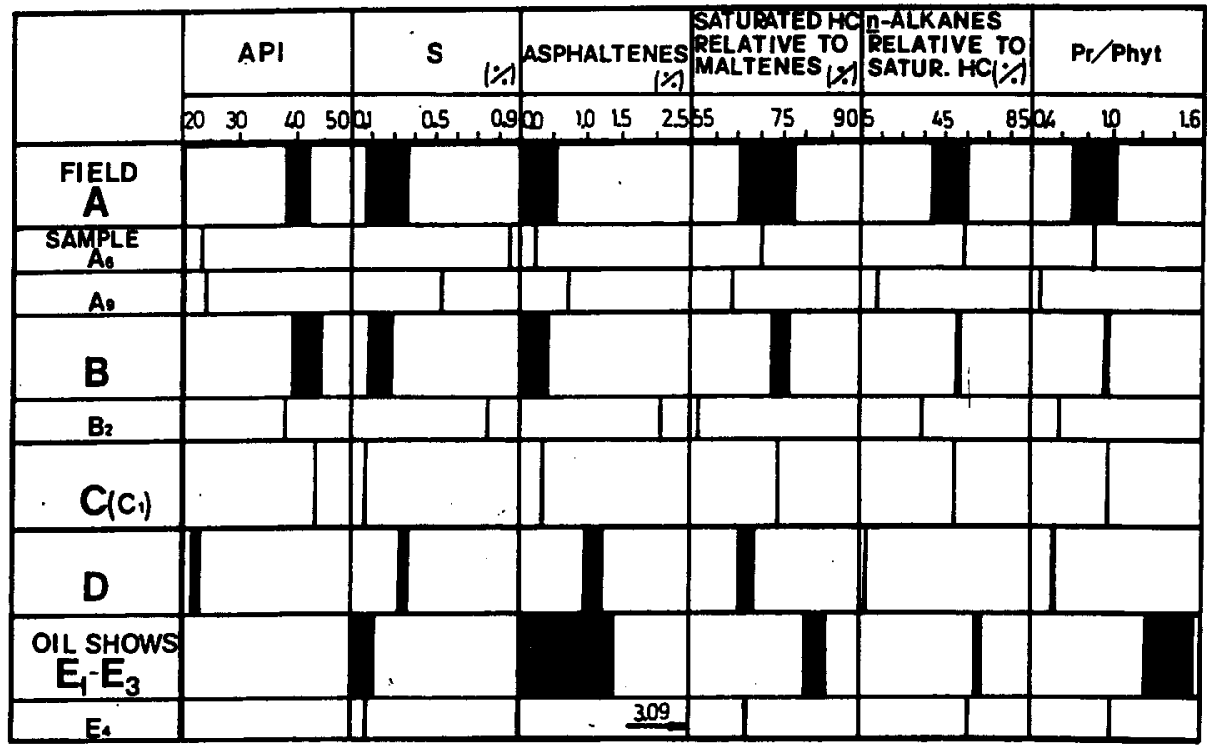

Fig. 4. Summary of the bulk and some of the specific parameters for individual fields A-D and oils shows $\mathrm{E}_{1}-\mathrm{E}_{4}$.

ratio ( 0.66 vs $0.90-0.94)$. Nevertheless, the values of these parameters are not close to those found for oil $A_{9}$. Therefore, in spite of the fact that oil $B_{2}$ probably does not belong to the same type as the other two oils from field $B$, it could not be classified into the same genetic type with the oil $A_{9}$.

Sample $C_{1}$ from the oil field $C$, according to all determined bulk parameters (Fig. 4), is similar to oils $B_{1}, B_{3}$ and $A_{1}-A_{8}$, suggesting that it belongs to the same oil type.

Samples $D_{1}$ and $D_{2}$, from oil field $D$, have similar values, but differ substantially from all the other oils, except oil $A_{9}$, suggesting a possible classification into the same group with the latter. Almost complete absence of $n$-alkanes in oils $D_{1}$ and $D_{2}$ could be explained by a moderate biodegradation, as in the case of $\mathbf{A}_{\mathbf{9}}$.

Three samples from the oil shows $E_{1}, E_{2}$ and $E_{3}$ have close parameter values, but differ considerably from other oils from fields $A-D$, as well as from oil $E_{4}$. Samples $E_{1}-E_{3}$ have a high percentage of $n$-alkanes $(66.97-71.11 \%)$ and a high $\mathrm{Pr} / \mathrm{Ph}$ ratio (1.29-1.65).

The oil $E_{4}$ differs from samples $E_{1}-E_{3}$ in most of the parameters, particularly by the $\mathrm{Pr} / \mathrm{Ph}$ ratio (0.93), but is similar to oils from the Banat depression $A_{1}-A_{8}, B_{1}, B_{3}$ and $C_{1}$.

On the basis of the examined bulk parameters as well as percentage of $n$-alkanes and $\mathrm{Pr} / \mathrm{Ph}$ ratio, the 19 oils could be classified into four groups, i.e. types: (1) $A_{1}-A_{9}, B_{1}, B_{3}, C_{1}$ and $E_{4}$; (2) $A_{9}, D_{1}$ and $D_{2}$; (3) $E_{1}-E_{3} ;$ (4) $B_{2}$.

The essence of the more precise classification of the examined oils on the basis of parameters presented in Fig. 4, relative to the differentiation based only on group composition (Fig. 3), consisted in separating samples $A_{9}, D_{1}$ and $D_{2}$ into a distinct group. Distinctive API gravity, \% sulfur, \% asphaltenes and \% $n$-alkanes of these three samples compared to other oils is most probably due to moderate biodegradation. Further confirmation for the observed biodegradation of these three crude oils is obtained from the reservoir temperatures shown in Fig. 2. Reservoir temperatures of these three oils are $\leqslant 66^{\circ} \mathrm{C}$. This is below the limit which was shown by Philippi (1977) to be the cut-off temperature of microbial transformation of petroleum in reservoirs. Since so far the paleotemperatures of these reservoirs have not been determined, the period when biodegradation occurred cannot be surely defined.

\section{Correlations based on source parameters}

According to the distributions and interrelationships of the biological marker compounds, i.e. $n$-alkanes, $\mathrm{C}_{27}-\mathrm{C}_{29}$ steranes, tricyclic terpanes and pentacyclic triterpanes, the oils from fields $A, B, C$ and $D$ (of the Banat and South Backa depressions) can be satisfactorily correlated with each other. On the other hand, according to most of the source parameters, these oils differ considerably from oils $E_{1}-E_{4}$ of the Kostolac depression (Figs 5 and 6). Thus, all the oils from the Banat depression fields, except the sample A, which possibly was moderately biodegraded, have a smooth distribution of $\boldsymbol{n}$-alkanes in the range $C_{14}-C_{39}$, with maxima at $C_{18}-C_{22}$, while oils $E_{1}-E_{4}$ have a slight domination of odd carbon numbered $n$-alkanes in the range $C_{23}-C_{27}$. Gas chromatograms of saturated hydrocarbons of two oils with similar maturity (cf. Table 2) are given as examples in Fig. 5 [A $A_{7}$ in Fig. 5(a) and $E_{3}$ in Fig. 5(b)]. The observed differences in the distribution of $n$-alkanes may indicate a higher contribution of terrestrial organic 


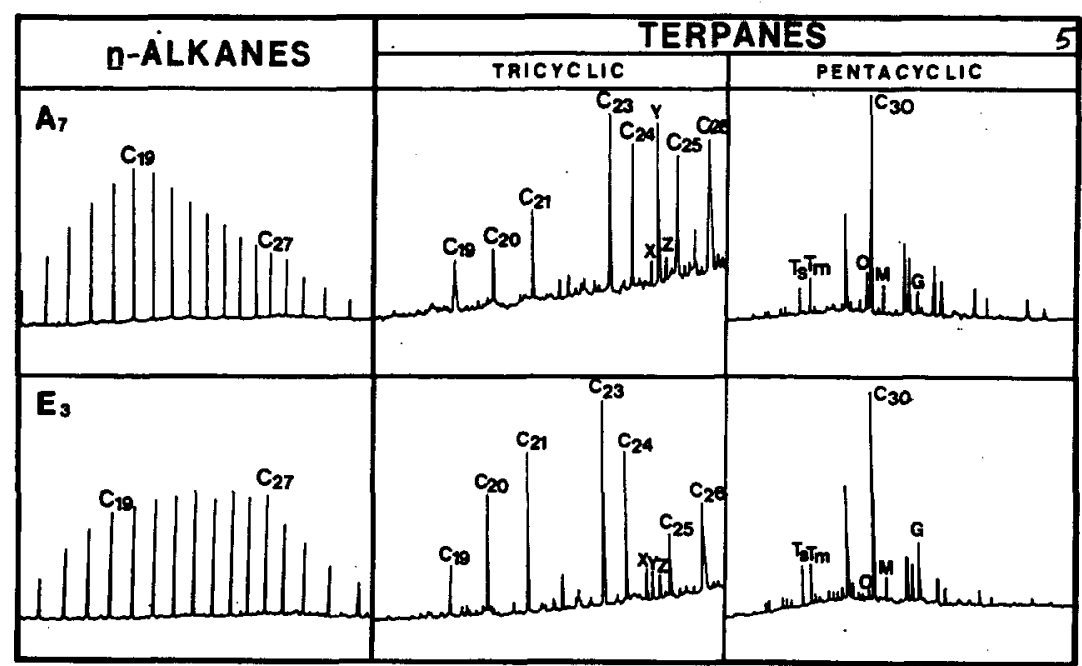

Fig. 5. Distributions of $n$-alkanes, tri- and pentacyclic terpanes of two particular oils, illustrating the differences in the source material between the Kostolac and Banat depressions. $X, Y, Z=$ unidentified peaks. Ts $=18 \alpha(\mathrm{H})-22,29,30$-trisnorneohopane; $T \mathrm{~m}=17 \alpha(\mathrm{H})-22,29,30$-trisnorhopane; $\mathrm{M}=$ moretane; $\mathrm{G}=$ gammacerane; $\mathbf{O}=$ oleanane.

matter from the source rocks of oils $E_{1}-E_{4}$ compared to the source rocks for the oils from the A, B and C fields.

The distribution of $5 \alpha(\mathrm{H}), 14 \alpha(\mathrm{H}), 17 \alpha(\mathrm{H})(20 \mathrm{R})$ $\mathrm{C}_{27}-\mathrm{C}_{29}$ steranes, based on $m / z 217$ fragmentograms, introduced in a triangular diagram (Fig. 6), corroborates that different sedimentation environments were responsible for oils $A, B, C$ and $D$ (i.e. open sea) and oils $E_{1}-E_{4}$ (bays and estuaries).

The composition and distribution of tricyclic terpanes [examples are given in Figs 5(a) and 5(b)], based on $m / z 191$ fragmentograms in the oils from fields $A-D$, differ from those in oils $E_{1}-E_{4}$. The fragmentograms show that all oils contain a homologous $\mathrm{C}_{19}-\mathrm{C}_{26}$ series. However, the samples A-D contain less $C_{19}-C_{21}$ relative to higher, $C_{23}-C_{26}$ members, in contrast to oils $E_{1}-E_{4}$. Furthermore, the distribution of unidentified peaks $X, Y$ and $Z$ (Fig. 5), located between the $C_{24}$ and $C_{25}$ members, is also different. Without exception, peak $\mathrm{Y}$ is more pronounced than the $C_{25}$ peak in oils $A-D$, in contrast to oils $E_{1}-E_{4}$ where the intensities of peaks $X, Y$ and $\mathrm{Z}$ did not differ much.

According to some authors (Aquino Neto et al., 1983; Moldowan et al., 1983), $C_{19}-C_{30}$ tricyclic terpanes are indicators of marine origin. However, the

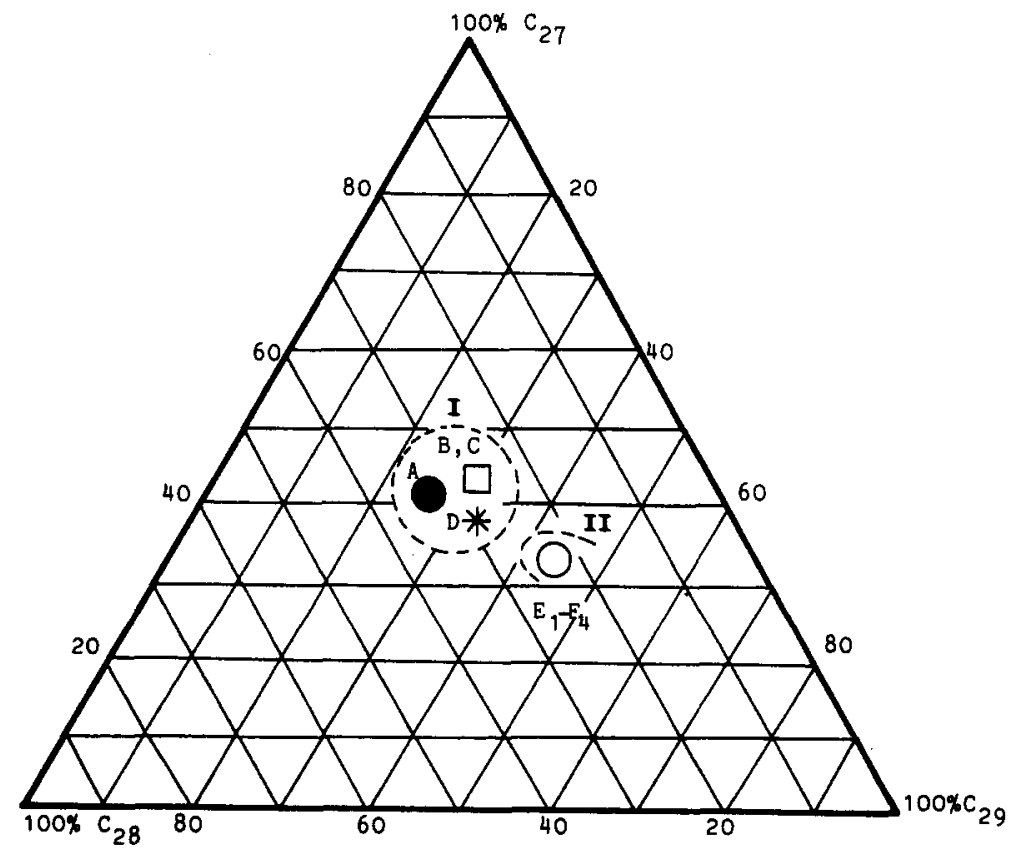

Fig. 6. Distribution of $\alpha \alpha \alpha(20 \mathrm{R}) \mathrm{C}_{27}-\mathrm{C}_{29}$ steranes, a parameter indicating origin (e.g. Waples, 1985). 
$\mathrm{C}_{19}$ and $\mathrm{C}_{20}$ tricyclic terpanes are also presumed to originate from vascular terrestrial plants (Reed, 1977; Simoneit, 1977). Abundance of tricyclic terpanes in oils $E_{1}-E_{4}$ (i.e. abundant $C_{19}$ and $C_{20}$ ) is in agreement with the distribution of $n$-alkanes and $C_{27}-C_{29} \alpha \alpha$ (20R) steranes, providing additional evidence that sediments with a larger relative amount of terrestrial organic material were responsible for generating oils $E_{1}-E_{4}$, distinguishing them from oils $A-D$. The maturity of oils $E_{1}-E_{4}$, as will be shown later by maturation parameters, did not differ much from those of oils A-D. Therefore, the difference in the distribution of $\mathrm{C}_{19}-\mathrm{C}_{21}$ tricyclic terpanes could not be attributed to thermal stress (Aquino Neto et al., 1983; Ekweozor and Strausz, 1983).

On the basis of the distribution in the $\mathrm{C}_{29}-\mathrm{C}_{35}$ hopane series, typical for moderately mature to mature oils [examples of $m / z 191$ fragmentograms are given in Figs 5(a) and 5(b)], samples $A-D$ do not differ from oils $E_{1}-E_{4}$. However, the oils $E_{1}-E_{4}$ contained considerable amounts of gammacerane, often observed in oils of terrestrial origin (Seifert $\boldsymbol{e t}$ al., 1983), contrary to oils A-D which contained just traces of gammacerane.

The distribution of $n$-alkanes, the $\mathrm{Pr} / \mathrm{Ph}$ ratio, the distribution of steranes and smaller tricyclic terpanes, and the content of gammacerane, suggest that oils from fields $A-D$ are predominantly of marine, and oils $E_{1}-E_{4}$ of terrestrial origin. Nevertheless, surprisingly, the oils $E_{1}-E_{4}$ contained very small quantities of oleanane (oleanane $/ \mathrm{C}_{30}$ hopane $=0.03-0.07$ ), an indicator of terrestrial origin (Riva et al., 1986), while this triterpane was found in the oils $A-D$ in much higher relative concentrations (oleanane/ $C_{30}$ hopane $=0.14-0.20$ ) with the exception of samples $B_{1}$ and $A_{8}(0.07$ and 0.09 , respectively). This observation

Table 1. Parameters which may be indicative of the distance of oil migration for the analyzed oils

\begin{tabular}{|c|c|c|c|}
\hline & $\begin{array}{c}13 \beta(\mathrm{H}), 17 \alpha(\mathrm{H}),(20 \mathrm{~S}) \text {-Diasterane } \\
14 \alpha(\mathrm{H}), 17 \alpha(\mathrm{H}),(20 \mathrm{R}) \text {-Sterane } \\
-\mathrm{C}_{27}+\mathrm{C}_{28}+\mathrm{C}_{29}\end{array}$ & $\%$ NSO & $\frac{\% \text { Saturated HC}}{\% \text { Aromatics }}$ \\
\hline $\begin{array}{l}A_{1} \\
A_{2} \\
A_{3} \\
A_{4} \\
A_{5} \\
A_{6} \\
A_{7} \\
A_{8} \\
A_{9}\end{array}$ & $\begin{array}{l}0.28 \\
0.25 \\
0.23 \\
0.27 \\
0.27 \\
0.27 \\
0.22 \\
0.30 \\
0.24 \\
\end{array}$ & $\begin{array}{r}8.32 \\
11.32 \\
5.87 \\
8.76 \\
12.32 \\
9.20 \\
15.55 \\
8.44 \\
13.56\end{array}$ & $\begin{array}{l}9.88 \\
5.45 \\
5.86 \\
6.23 \\
5.88 \\
5.22 \\
5.45 \\
8.56 \\
3.74 \\
\end{array}$ \\
\hline $\begin{array}{l}\mathrm{B}_{1} \\
\mathrm{~B}_{2} \\
\mathrm{~B}_{3}\end{array}$ & $\begin{array}{l}0.35 \\
0.23 \\
0.24\end{array}$ & $\begin{array}{r}5.51 \\
21.21 \\
9.29 \\
\end{array}$ & $\begin{array}{l}6.79 \\
3.70 \\
7.12 \\
\end{array}$ \\
\hline $\mathrm{C}_{1}$ & 0.25 & 10.13 & 11.15 \\
\hline $\begin{array}{l}\mathrm{D}_{1} \\
\mathrm{D}_{2} \\
\end{array}$ & $\begin{array}{l}0.28 \\
0.28\end{array}$ & $\begin{array}{l}13.38 \\
14.99 \\
\end{array}$ & $\begin{array}{l}4.47 \\
4.24 \\
\end{array}$ \\
\hline $\begin{array}{l}\mathbf{E}_{1} \\
\mathbf{E}_{2} \\
\mathbf{E}_{3} \\
\mathbf{E}_{4} \\
\end{array}$ & $\begin{array}{l}0.54 \\
0.22 \\
0.23 \\
0.13\end{array}$ & $\begin{array}{r}4.83 \\
3.68 \\
6.45 \\
12.63 \\
\end{array}$ & $\begin{array}{r}13.40 \\
8.89 \\
8.33 \\
6.65 \\
\end{array}$ \\
\hline
\end{tabular}

suggests that oils $A-D$ are not exclusively of marine origin and the oils $E_{1}-E_{4}$ not only of terrestrial origin.

In contrast to the conclusions based on bulk parameters, molecular source parameters indicate that the examined oils could be classified into only two genetic types, i.e. oils $A-D$ generated in source rocks of predominantly marine origin and oils $E_{1}-E_{4}$ originating from source rocks with an additional extensive terrestrial input. However, the results obtained suggest that in some cases the oils from individual depressions originate from different source rocks. This is indicated by the values of parameters which may be indicative of the distance of oil migration and which sometimes differ even for oils from reservoirs that are close together (Fig. 1). The following parameters were considered: the ratio \% saturated hydrocarbons $/ \%$ aromatic hydrocarbons which is higher with longer migration, $\%$ of NSOcompounds which is lower with longer migration (e.g. Waples, 1985), and molecular sterane parameter, the ratio $13 \beta(\mathrm{H}), 17 \alpha(\mathrm{H})(20 \mathrm{~S})$-diasterane $/ 14 \alpha(\mathrm{H})$, $17 \alpha(\mathrm{H})(20 \mathrm{R})$-sterane $\left(\mathrm{C}_{27}-\mathrm{C}_{29}\right)$, which, presuming that geochromatography occurs during migration, increases with longer migration distance (Seifert and Moldowan, 1981; Philp, 1985) (Table 1).

\section{Correlations based on maturation parameters}

According to the maturation parameters $\alpha \alpha(20 S) /$ $\alpha \alpha(20 R) C_{29}$ steranes and (22S)/(22R) $C_{32}$ hopanes (Table 2), the maturity of the 19 oils is uniform and at equilibrium (values around 1.0 and 1.5 , respectively; e.g., Waples, 1985).

The ratios of isoprenoid hydrocarbons pristane and phytane with the $n$-alkanes $C_{17}$ and $C_{18}$, respectively, also indicate uniformity and high maturity of the oils (Fig. 7). However, the oils $A_{9}, D_{1}$ and $D_{2}$ differ from the others on the basis of their moderate biodegradation indicated earlier in the group parameters discussion of these three oils.

Also, on the basis of further sterane and terpane maturation parameters such as: $\beta \beta(20 \mathrm{R}) / \alpha \alpha(20 \mathrm{R}) \mathrm{C}_{29}$ steranes; $\mathrm{C}_{27} \alpha \alpha$ (20R) sterane/ $\beta \alpha$ (20R) diasterane; $\mathrm{Tm} /$ Ts; $C_{19} / C_{23}$ tricyclic terpanes; $C_{30}$ hopane $/ C_{29}+C_{30}$ moretane (e.g. Seifert and Moldowan, 1978; Palacas et al., 1986), the oils within the individual oil fields could be differentiated to a certain degree (Table 2).

The ratios $T \mathrm{~m} / \mathrm{Ts}$ and $\mathrm{C}_{19} / \mathrm{C}_{23}$ tricyclic terpanes are considered to be among the useful maturation parameters for the oils derived from source rocks containing similar types of organic matter (Palacas et al. 1986; Philp, 1985). On the basis of these two parameters the oils from each examined field were ranged according to increasing maturity (Table 2). Other parameters from Table 2 corroborated these maturity ranges pretty good.

\section{CONCLUSIONS}

On the basis of bulk correlation parameters as well as content of $\boldsymbol{n}$-alkanes and pristane to phytane 
Table 2. Correlation of analyzed oils according to maturity parameters

\begin{tabular}{|c|c|c|c|c|c|c|c|}
\hline & \multicolumn{4}{|c|}{ Terpanes } & \multicolumn{3}{|c|}{ Steranes } \\
\hline & $\mathrm{Tm} / \mathrm{Ts}$ & $\begin{array}{l}\mathrm{C}_{19} / \mathrm{C}_{23} \\
\text { Tricyclic }\end{array}$ & $\frac{\mathrm{C}_{30} \text {-Hopane }}{\mathrm{C}_{29}+\mathrm{C}_{30}-\text { Moretane }}$ & $\frac{22 S}{22 R}-C_{32}$ Hopane & $\frac{\beta \beta 20 \mathrm{R}}{\alpha \alpha 20 \mathrm{R}}-\mathrm{C}_{x}$ & $\frac{\alpha a 20 \mathrm{R}-\mathrm{C}_{27} \text { Ster. }}{\beta \alpha 20 \mathrm{R}-\mathrm{C}_{27} \text { Diast. }}$ & $\frac{\alpha \alpha 20 S}{\alpha \alpha 20 R}-C_{29}$ \\
\hline $\begin{array}{l}A_{3} \\
A_{1} \\
A_{4} \\
A_{8} \\
A_{8} \\
A_{9} \\
A_{2} \\
A_{3} \\
A_{7}\end{array}$ & $\begin{array}{l}0.77 \\
0.82 \\
0.86 \\
0.88 \\
0.92 \\
1.09 \\
1.10 \\
1.18 \\
1.33\end{array}$ & $\begin{array}{l}\text { ND } \\
0.50 \\
0.52 \\
0.58 \\
0.48 \\
0.31 \\
0.31 \\
0.29 \\
0.30 \\
\end{array}$ & $\begin{array}{l}7.00 \\
6.08 \\
7.20 \\
7.05 \\
7.00 \\
6.72 \\
6.86 \\
6.34 \\
5.54 \\
\end{array}$ & $\begin{array}{l}1.36 \\
1.45 \\
1.45 \\
1.48 \\
1.51 \\
1.41 \\
1.50 \\
1.50 \\
1.38 \\
\end{array}$ & $\begin{array}{l}1.37 \\
1.32 \\
1.46 \\
1.56 \\
1.25 \\
1.25 \\
1.26 \\
1.26 \\
1.02\end{array}$ & $\begin{array}{l}3.33 \\
3.56 \\
4.07 \\
3.00 \\
4.14 \\
4.66 \\
4.28 \\
5.42 \\
5.00\end{array}$ & $\begin{array}{l}0.93 \\
1.04 \\
0.96 \\
0.75 \\
0.89 \\
0.98 \\
0.91 \\
0.90 \\
0.84\end{array}$ \\
\hline $\begin{array}{l}\mathbf{B}_{1} \\
\mathbf{B}_{2} \\
\mathbf{B}_{3}\end{array}$ & $\begin{array}{l}0.64 \\
1.18 \\
1.30 \\
\end{array}$ & $\begin{array}{l}\text { ND } \\
0.28 \\
0.25 \\
\end{array}$ & $\begin{array}{l}6.60 \\
6.25 \\
5.68\end{array}$ & $\begin{array}{l}1.30 \\
1.41 \\
1.45\end{array}$ & $\begin{array}{l}1.38 \\
1.25 \\
1.22 \\
\end{array}$ & $\begin{array}{l}2.53 \\
5.23 \\
5.00\end{array}$ & $\begin{array}{l}1.00 \\
0.91 \\
0.93\end{array}$ \\
\hline$\overline{c_{1}}$ & 0.66 & 0.62 & 6.60 & 1.50 & 1.37 & 4.57 & 0.98 \\
\hline $\begin{array}{l}\mathrm{D}_{1} \\
\mathrm{D}_{2}\end{array}$ & $\begin{array}{l}0.96 \\
1.07 \\
\end{array}$ & $\begin{array}{l}0.44 \\
0.51 \\
\end{array}$ & $\begin{array}{l}6.45 \\
6.55 \\
\end{array}$ & $\begin{array}{l}1.36 \\
1.24 \\
\end{array}$ & $\begin{array}{l}1.59 \\
1.51 \\
\end{array}$ & $\begin{array}{l}3.75 \\
3.25\end{array}$ & $\begin{array}{l}1.05 \\
1.08\end{array}$ \\
\hline $\begin{array}{l}E_{1} \\
E_{2} \\
E_{3} \\
E_{4}\end{array}$ & $\begin{array}{l}0.60 \\
1.00 \\
1.00 \\
1.80\end{array}$ & $\begin{array}{l}0.40 \\
0.19 \\
0.23 \\
0.12\end{array}$ & $\begin{array}{l}5.50 \\
6.54 \\
5.31 \\
4.53\end{array}$ & $\begin{array}{l}1.42 \\
1.46 \\
1.50 \\
1.25\end{array}$ & $\begin{array}{l}1.56 \\
1.41 \\
1.01 \\
0.72\end{array}$ & $\begin{array}{r}0.93 \\
7.40 \\
4.90 \\
28.00\end{array}$ & $\begin{array}{l}1.14 \\
1.00 \\
0.99 \\
1.00\end{array}$ \\
\hline
\end{tabular}

ratios, the oils from two oil-gas fields, $A$ and $B$, and an oil from field $C$ from the Banat depression, the oils from the oil field D (South Bačka depression) and the oils $E_{1}-E_{4}$ from the Kostolac depression are classified into four separate groups. However, introduction of more reliable molecular parameters suggest limitation of the classification of these oils into only two genetic types: type I including oils from fields $A-D$, and type II involving oil shows $E_{1}-E_{4}$. This classification was based on molecular source parameters such as distribution and abundance of $n$-alkanes, pristane and phytane, $\alpha \alpha(20 \mathrm{R}) \mathrm{C}_{27}-\mathrm{C}_{29}$ steranes, tricyclic $\mathrm{C}_{19-}$ $\mathrm{C}_{26}$ terpanes and pentacyclic triterpanes, as well as gammacerane and oleanane. The suggested classification differed from an earlier classification of oils from fields A-D into three types, based on trace elements (Sarković, 1972; Šaban et al., 1983) and indicated that classification of oils into genetic types based on one parameter only is not quite reliable.

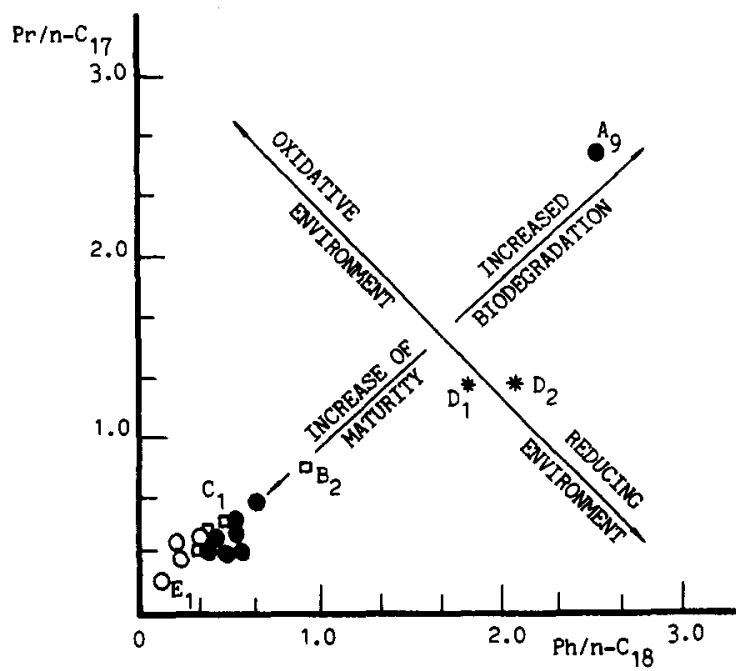

Fig. 7. Relationship of $\mathrm{Pr} / n-\mathrm{C}_{17}$ and $\mathrm{Ph} / n-\mathrm{C}_{18}$, indicating the maturity of oils (Waples, 1985).
Different values of parameters which may be indicative of the distance of oil migration observed for oils from closely located reservoirs may indicate diverse locations of source rocks even of oils within a same genetic type.

All examined oils were found to be of high and relatively uniform maturity based on the two most reliable biomarker maturation parameters, (22S)/ (22R) $C_{32}$ hopane and $\alpha \alpha(20 S) / \alpha \alpha(20 R) C_{29}$ sterane. On the basis of other maturation parameters, calculated from the distributions of tri- and pentacyclic terpanes and steranes, the oils from the same oil fields are slightly differentiated.

The oils are not biodegraded with the exception of samples $A_{9}, D_{1}$ and $D_{2}$, which are moderately biodegraded.

Acknowledgements - The authors are grateful to Nafta-Gas, Novi Sad, for the interest in this work and for the financial help. The assistance of Mr Forche with the GC-MS runs, from the Institute for Petroleum Research, ClausthalZellerfeld, F.R.G., is greatly appreciated. This work was supported in part by the Research Fund of the S.R. Serbia (Yugoslavia).

\section{REFERENCES}

Aksin B. (1967) Theoretical problems concerning the classification of oil and gas deposits. The significance of the classification for exploration, with a special consideration of the deposits in Banat (in Serbo-Croatian). Institute for Geological and Geophysical Investigations, Belgrade.

Aquino Neto F. R.; Trendel J. M., Restle A., Connan J. and Albrecht P. A. (1983) Occurrence and formation of tricyclic and tetracyclic terpanes in sediments and petroleum. In Advances in Organic Geochemistry 1981 (Edited by Bjorøy M. et al.), pp. 659-667. Wiley, Chichester.

Ekweozor C. M. and Strausz O. P. (1983) Tricyclic terpanes in the Athabasca oil sands: Their geochemistry. In Aduances in Organic Geochemistry 1981 (Edited by Bjorey M. et al.), pp. 746-766. Wiley, Chichester.

McKirdy D. M., Aldridge A. K. and Ypma P. J. M. (1983) A geochemical comparison of some crude oils from Pre-ordovician carbonate rocks. In Advances in Organic 
Geochemistry 1981 (Edited by Bjorøy M. et al.), pp. $\hat{9} \hat{y}-$ 107. Wiley, Chichester.

Moldowan J. M., Seifert W. K. and Gallegos E. J. (1983) Identification of an extended series of tricyclic terpanes in petroleum. Geochim. Cosmochin. Acta 47, 1531-1534.

Palacas J. G., Monopolis D., Nicolaou C. A. and Anders D. E. (1986) Geochemical correlation of surface and subsurface oils, Western Greece. In Advances in Organic Geochemistry 1985 (Edited by Leythaeuser D. and Rullkötter J.) Org. Geochem. 10, 417-423. Pergamon Press, Oxford.

Philippi G. J. (1977) On the depth, time and mechanism of origin of the heavy to medium-gravity naphthenic crude oils. Geochim. Cosmochim. Acta 41, 33-52.

Philp R. P. (1985) In Fossil Fuel Biomarkers. Elsevier, Amsterdam.

Reed W. E. (1977) Molecular composition of weathered petroleum and comparison with its possible source. Geochim. Cosmochim. Acta 41, 237-247.

Riva A., Salvatori T., Cavaliere R., Ricchiuto T. and Novelli L. (1986) Origin of oils in Po Basin, North Italy. In Advances in Organic Geochemistry 1985 (Edited by Leythaeuser D. and Rullkötter J.). Org. Geochem. 10, 391-400. Pergamon Press, Oxford.

Seifert W. K. and Moldowan J. M. (1978) Applications of steranes, terpanes and monoaromatics to the maturation, migration and source of crude oils. Geochim. Cosmochim. Acta 42, 77-95.
Seifert W. K. and Moldowan J. M. (1979) The effect of biodegradation on steranes and terpanes in crude oils. Geochim. Cosmochim. Acta 43, 111-126.

Seifert W. K. and Moldowan J. M. (1981) Paleoreconstruction by biological markers. Geochim. Cosmochim. Acta 45, 783-794.

Seifert W. K., Carison R. M. K, and Moldowan J. M. (1983) Geomimetic synthesis structure assignment and geochemical correlation application of monoaromatized petroleum steroids. In Advances in Organic Geochemistry 1981 (Edited by Bjorøy M. et al.), pp. 710-724. Wiley, Chichester.

Simoneit B. R. T. (1977) Diterpenoid compounds and other lipids in deep-sea sediments and their geochemical significance. Geochim. Cosmochim. Acta 41, 463-476.

Saban M., Vitorović O. and Vitorović D. (1984) Correlation of crude oils from Vojvodina (Yugoslavia) based on trace elements. In Characterization of Heavy Crude Oils and Petroleum Residues. Collection Colloques et Sèminaires 40, pp. 122-127. Editions Technip, Paris.

Sarković M. (1972) Ph.D. thesis, University of Beograd, Beograd, Yugosiavia.

Waples D. W. (1985) Geochemistry in Petroleum Exploration. Inter. Human Resources Development Corporation, Boston.

Welte D. H., Hagemann H. W., Hollerbach A., Leythaeuser D. and Stahl W. (1975) Correlation between petroleum and source rock. Proc. 9th World Pet. Congr., pp. 179191. 